\title{
OTR4 Determinação e comparação dos pontos de corte ideais de duas metodologias para o micro PRNT de sarampo
}

Vanessa de Oliveira Santos ${ }^{1}$, Marisol Simões ${ }^{1}$, Ana Carolina dos Reis Albuquerque Cajaraville ${ }^{1}$, José Henrique Rezende Linhares ${ }^{1}$, Emily Hime Miranda ${ }^{1}$, Sheila Maria Barbosa de Lima ${ }^{1}$

${ }^{1}$ Bio-Manguinhos, Fiocruz, Rio de Janeiro, RJ

Introdução: O sarampo é uma doença viral exantemática da infância, ocasionada pelo vírus pertencente à família Paramyxoviridae, subfamília Paramyxovirinae, gênero Morbillivirus. A doença é altamente contagiosa e pode apresentar quadro clínico leve a moderadamente grave. Uma alta cobertura vacinal (95\%), exigida para um vírus de elevada infecciosidade como o sarampo, não ocorre de modo homogêneo no mundo, dificultando a sua erradicação. No Brasil, a imunização para sarampo é realizada através da tríplice viral no Programa Nacional de Imunização, conferindo aproximadamente 98\% de soroconversão. O Teste de Neutralização por Redução de Placas de Lise (PRNT) é considerado o método sorológico de referência para quantificação de anticorpos neutralizantes, que conferem imunidade protetora, desempenhando importante papel na avaliação da eficácia vacinal.

Objetivo: Diante disto, observou-se a necessidade de melhorias do micro PRNT de sarampo, visando minimizar as variações climáticas sujeitas ao teste no protocolo já estabelecido, determinando o seu ponto de corte ideal e comparando os títulos de ambas as metodologias, possibilitando a geração de resultados mais acurados.

Metodologia: Para isto, foi realizado micro PRNT de 200 soros utilizando-se uma nova metodologia (neutralização e adsorção a 37으 em estufa de $5 \%$ CO2 e utilização de meio sem HEPES), em comparação à metodologia preconizada pelo laboratório (neutralização em temperatura ambiente, adsorção em estufa BOD e utilização de meio com HEPES). Os resultados obtidos foram organizados e analisados em programa estatístico, correlacionando os títulos de anticorpos neutralizantes obtidos pelas diferentes metodologias e avaliando se as mudanças metodológicas interferiram nos resultados.

Resultados: Ao analisar os resultados obtidos das amostras, eles se apresentaram em uma separação bem definida de duas populações de soros (negativos e positivos), mostrando que o ponto de corte ideal para ambas as metodologias foi de $2,3 \mathrm{Log} 10 \mathrm{mUl} / \mathrm{mL}(200 \mathrm{mUI} / \mathrm{mL})$ ou 1,4 Log10 recíproca da diluição (1:25). Dos 200 soros analisados, 62 e 63 soros foram considerados negativos (abaixo do ponto de corte) para a antiga e a nova metodologia, respectivamente. 
Conclusão: Os dois métodos geraram resultados com o mesmo perfil de dispersão e os mesmos pontos de corte ideais para definir soropositividade para sarampo. Sendo assim, as mudanças realizadas no micro PRNT de sarampo não geraram mudanças para a classificação de soro positividade ou soro negatividade dos títulos de anticorpos neutralizantes, ou seja, a utilização de temperatura e concentração de gases estáveis não interferiu nos títulos de anticorpos neutralizantes obtidos pelo PRNT.

Palavras-Chave: Sarampo, Micro PRNT, Ponto de Corte, Anticorpos Neutralizantes 